\title{
David Hume e as finanças de James I
}

\section{ROGERIO ARTHMAR*}

RESUMO: Este artigo examina a análise de David Hume realizada em seu livro História da Inglaterra, da luta entre o parlamento e o rei James I sobre as finanças da coroa durante o primeiro trimestre do século XVII. Inicialmente, são apresentados os principais elementos políticos por trás da briga no coração do poder político da Inglaterra, seguidos por comentários do escritor escocês sobre as finanças reais, com ênfase nos seus pontos de vista sobre as receitas e despesas da Coroa durante o reinado de James I. No final são recuperados os fatores de longo prazo elencados como determinantes da nova postura parlamentar. PALAVRAS-CHAVE: finanças da Coroa; Rei James I; parlamento; tributação; liberdade.

ABSTRACT: David Hume and the finances of James I. This paper examines David Hume's analysis, conducted in his book History of England, of the struggle between parliament and King James I over the Crown finances during the first quarter of the $17^{\text {th }}$ century. Initially, it presents the main political elements behind the quarrel played out in the heart of England's political power, followed by the Scottish writer's comments on the royal finances, with emphasis on his views about the Crown receipts and expenditures during James's I reign. In the end, the long run determinants of the parliamentary resistance to regal power identified by Hume are retrieved.

KEYWORDS: crown finances; King James I; parliament; taxation; liberty. JEL Classification: B11; B31, N4.

\section{INTRODUÇÃO}

A extensa obra histórica de David Hume tem despertado escassa atenção entre os economistas, lacuna tão mais inquietante quando se admite ter sido este, com efeito, um dos campos de reflexão de maior interesse do pensador escocês. Edgar A. J. Johnson (1960, pp. 161-181) e William L. Taylor (1985, pp. 118-133) privilegiam

\footnotetext{
" UFES — Universidade Federal do Espírito Santo. E-mail: rarthmar@gmail.com. Submetido: 4/janeiro/2013; Aprovado: 7/julho/2014.
} 
a posição singular de Hume como autor de transição no final do período mercantilista, mencionando a sua defesa ocasional do protecionismo, mas destacando também a ênfase por ele concedida à ação do price-specie flow em corrigir automaticamente a balança comercial. Já em sua revisão das raízes remotas do liberalismo, William D. Grampp (1965, v. 2, pp. 46-48) argumenta que apesar de Hume rejeitar a tese do contrato social em favor da autoridade estabelecida, isso não afastaria o princípio último de que os governos deveriam estar baseados no consenso de seus subordinados, como defendido pelos autores liberais posteriores. Mais recentemente, Carl Wennerlind e Margaret Schabas (2008) reuniram diversos estudos sobre as anotações econômicas de Hume relativamente à moeda, ao comércio e ao valor, entre temas similares, mas sem aprofundar em seus escritos históricos.

Seja qual for o motivo, tal omissão não parece justificável. A partir de 1752, quando assume a direção da Biblioteca dos Advogados de Edimburgo, Hume empenhar-se-ia por dez anos na redação dos seis volumes da obra que viria a ser conhecida como History of England (doravante History), a qual atingiria dezenas de edições e lhe traria celebridade universal ${ }^{1}$. Nas palavras de um biógrafo do pensador: "Naquele tempo, a History de Hume foi o seu trabalho mais famoso e, após a sua publicação, ele sempre insistiu em ser chamado historiador em vez de filósofo" (Graham, 2004, p. 222; veja-se, igualmente, Mossner, 1954, pp. 301-318)2. No conjunto do material, o governo do rei James I (1603-1625) foi considerado o mais importante da casa Stuart por definir o início das disputas entre concepções divergentes sobre o arranjo constitucional do país, deflagrando um processo que culminaria nas Guerras Civis (16421651) e, adiante, na Revolução Gloriosa (1688).

É importante mencionar que ao início do século XVII, apesar de não contar com um exército permanente, a realeza na Inglaterra já havia logrado constituir uma estrutura monárquica altamente centralizada, secundada por um parlamento com força política crescente, conformando um núcleo decisório no qual eram travados os grandes embates nacionais. Assim ocorreu devido à ausência de instituições regionais suficientemente representativas e autônomas capazes de desafiar a autoridade do Estado centralizado, até porque os proprietários de terras, autoridades máximas do poder local, detinham representação na Câmara dos Lordes. Ao mesmo tempo, os desenvolvimentos militares no continente, envolvendo a formação de grandes exércitos com elevado custo, mantiveram a Inglaterra afastada não só de uma invasão estrangeira, mas também incapacitada de interferir decisivamente nos assuntos europeus por mais de dois séculos desde o reinado de Henry VI

\footnotetext{
${ }^{1}$ Em 1754, Hume publica o primeiro volume da coleção, intitulado The History of Great Britain, containing the reigns of James I and Charles I, objeto de diversas críticas por propalar supostamente uma visão tory da Revolução Puritana. O segundo volume, sobre os Stuarts no período da restauração, chegou ao público em 1756. A história dos Tudors, também em dois volumes, viria a ser publicada em 1759. No ano de 1762, Hume completaria a série com The History of England from the invasion of Julius Caesar to the accession of Henry VII.

${ }^{2}$ A metodologia de estudo da história adotada por Hume é discutida por Norton e Popkin (1965, pp. ix-1) e Schmidt (2003, pp. 379-393); sobre o conteúdo de History, veja-se Wexler (1979, pp. 9-89), Schmidt (2003, pp. 393-413), O’Brien (2005, pp. 52-96) e Phillipson (2011, pp. 70-135).
} 
(1422-1461). Em relação a isso, o férreo controle parlamentar sobre as receitas extraordinárias da Coroa mostrou-se igualmente decisivo ao coibir os monarcas ingleses de empreenderem dispendiosas aventuras militares em solo europeu (Brewer, 1989, pp. 3-24).

Nesse contexto, o diagnóstico das finanças reais ao início do século XVII elaborado por Hume constitui-se instância singular de confluência de seus conhecimentos em filosofia, história e economia na análise de um aspecto essencial na formação da sociedade moderna. Para esse fim, o presente artigo reconstitui o entendimento de autor escocês sobre a evolução do cenário político e econômico da Inglaterra do século XVIII para, na sequência, remontar à sua interpretação sobre a origem da disputa entre os Comuns e o soberano. Na continuação, resgatam-se as considerações de Hume sobre as finanças da Coroa no início do século XVII. Ao final, apresentam-se os fatores de longo prazo por ele elencados como determinantes da nova postura parlamentar no período.

\section{ANTECEDENTES DA ABORDAGEM HISTÓRICA DE HUME}

As reflexões de Hume sobre o reino de James I podem ser mais bem compreendidas quando se tomam por base os textos compilados nos Essays (1742) e nos Political Discourses (1752). Hume, em seus escritos de cunho econômico, explica que a moeda teria a função exclusiva de facilitar a circulação de mercadorias, de modo que sua quantidade não exerceria impacto duradouro sobre a magnitude da riqueza. A única vantagem de uma larga disponibilidade doméstica de ouro decorreria da maior facilidade de pagamento de mercenários em tempos de guerra. Doutra forma, a fartura de dinheiro originada em um saldo comercial positivo, por exemplo, provocaria somente o encarecimento da produção do país e a redução da atratividade externa de seus artigos de exportação, aspecto invariavelmente negligenciado pelos autores mercantilistas. No curto prazo, porém, um ingresso acentuado de metais preciosos poderia gerar efeitos benéficos temporários na economia, uma vez que a distribuição da moeda adicional demandaria certo tempo durante o qual o aumento localizado nos gastos exerceria impacto positivo sobre as atividades produtivas. Tão logo o poder de compra suplementar se diluísse na sociedade, contudo, tal estímulo deixaria de existir. Desde o descobrimento das Índias Ocidentais, o volume de ouro e prata que afluíra a Europa fizera os preços triplicarem ou quadruplicarem na maior parte do continente, assinala Hume, embora o crescimento da produção houvesse atenuado a intensidade de tais reajustes (Hume, Of money, 1987, pp. 281-94).

Quanto à ação fiscal dos governantes, o filósofo escocês posiciona-se francamente contrário àqueles que propunham a funcionalidade da dívida pública sob o argumento de que os títulos correspondentes proveriam um tipo complementar de meio circulante capaz de expandir as vendas e os negócios. Além disso, tais papéis funcionariam, pretensamente, como uma reserva de valor conveniente à aplicação dos fundos ociosos dos comerciantes. Hume, ao contrário, entende a dívida pública prejudicial à economia pelo fato de os títulos correspondentes expulsarem o ouro e a 
prata de circulação, encarecendo os produtos em geral. Ainda, os impostos acrescidos para a amortização do débito acabariam recaindo sobre os bens de consumo dos pobres, piorando a sua condição e gerando pressão para aumentos dos salários. Não fosse isso o bastante, parte considerável da dívida seria apropriada por ociosos ou estrangeiros, encorajando a inatividade da nação e, ao mesmo tempo, tornando-a vulnerável aos interesses externos. Com o endividamento crescente, chegaria o momento em que os novos títulos emitidos deixariam de ser aceitos pelo público, os impostos resultariam insuficientes para cobrir os gastos correntes e nada mais seria pago aos credores da Coroa. Destruir-se-ia assim, de forma irresponsável, o crédito público e, em decorrência, a capacidade de a Inglaterra interferir decisivamente nos assuntos europeus (Hume, Of public credit, 1987, pp. 349-65).

Passando ao plano da política, Hume atribuiu ao princípio da simpatia não somente a condição de fundamento da sociabilidade entre os homens, mas também de divisão entre os grupos sociais, porquanto os indivíduos estariam propensos a se identificar com os que lhes fossem próximos, opondo-se radicalmente a tudo que lhes despertasse contrariedade. Surgiriam, desse modo, as facções políticas e as seitas religiosas, fontes de discórdias e guerras, voltadas a subverter as leis, a provocar animosidades e, no mais das vezes, a derrubar de forma violenta o sistema de governo sob o qual se constituíram. O novo fenômeno que Hume percebe em seu tempo, porém, consistia nas facções baseadas em princípios filosóficos que, na Inglaterra, passaram a definir, de um lado, o court party, congregando os amantes da ordem favoráveis à monarquia e, de outro, o country party, reunindo os apaixonados pela liberdade e defensores do parlamento (Hume, Of parties in general, Of the parties of Great Britain, 1987, pp. 54-72).

A partir de tal perspectiva, o pensador escocês repudia as teses dos teóricos partidários que remontavam a origem dos governos ao poder divino ou ao consenso voluntário dos homens. Na primeira hipótese, caso tudo estivesse compreendido no plano universal da Providência, a autoridade do soberano resultaria tão sagrada quanto à do pirata. Na segunda conjectura, objeta Hume, um acordo abrangente dificilmente se verificara entre os homens ao longo da história. O mais provável é que os primeiros governos bárbaros tivessem se organizado a partir da conquista ou da usurpação, à revelia dos desejos dos respectivos povos. Com a passagem do tempo, uma vez que cada geração não podia instituir um novo regime político, os indivíduos aprenderam a seguir a trilha de seus antepassados e a se conformar ao governo existente, o qual, porém, admitiria inovações graduais promovidas pela força da razão, da liberdade e da justiça (Hume, Of the original contract, 1987 , pp. 465-487).

A aceitação da autoridade por longo precedente não excluiria, contudo, as dissensões, o interesse próprio e as tentações peculiares à natureza humana. "Em todos os governos", escreve Hume, "existe uma luta visceral perpétua entre Autoridade e Liberdade, e nenhuma das duas pode prevalecer de forma absoluta nessa contenda" (Hume, Of the origin of government, 1987, p. 40, destaque no original). Em cada arranjo político, algum sacrifício da liberdade resultaria inevitável, enquanto a autoridade jamais poderia se encontrar despojada de freios. Neste ponto, Hume não deixa dúvidas tratar-se a liberdade, em sua leitura dos fatos, de situação histórica específica do tempo moderno na qual prevaleceriam, de uma parte, o balanceamen- 
to do poder entre as instâncias governantes da sociedade e, de outra, os direitos individuais, garantidos por leis originadas nos costumes e nas instituições.

O governo que, no linguajar comum, recebe a designação de livre, é aquele que admite a partição do poder entre os seus diversos componentes, cuja autoridade combinada não é superior a de qualquer monarca, o qual, no curso usual da administração, deve agir com base nas leis gerais e iguais, de conhecimento prévio de todos os seus membros e subordinados. Neste sentido, deve-se admitir, a liberdade é a perfeição da sociedade civil $^{3}$. (Hume, Of the origin of government, 1897, pp. 40-41)

De resto, Hume entende ser esta a condição alcançada pela Inglaterra no século XVIII após a Revolução Gloriosa de 1688. A tese dos autores whigs de uma pretensa luta imemorial pela liberdade no país não encontraria respaldo na história, dado que no período feudal o povo não dispunha de voz, sendo o jogo político exercido exclusivamente pelos reis e barões. ${ }^{4}$ Tampouco haveria uma antiga carta magna atemporal a ser recuperada no presente, porquanto naquela época pretérita vigorava o privilégio, enquanto a Câmara dos Comuns simplesmente inexistia. De resto, tais argumentos contra o poder real, com efeito, já haveriam perdido a razão de ser depois da coroação de William III (1689-1702) com o apoio conjunto de whigs e tories. "O plano da liberdade está estabelecido; os seus felizes efeitos se provaram pela experiência; um longo intervalo de tempo conferiu-lhe estabilidade" (Hume, Of the coalition of parties, 1987, p. 501).

Nos estados livres sujeitos à autoridade estabelecida, explica Hume, prevalece o império da lei, o qual proporciona segurança e, desse modo, estimula a curiosidade e o conhecimento. Com o avanço das cidades, do comércio e da produção manufatureira, os agricultores encontram motivação para produzir além de suas necessidades, criando-se assim mais riquezas, estimulando-se as artes e as ciências e fortalecendo-se o Estado, que passa a dispor de recursos para sustentar os seus empreendimentos bélicos ou administrativos (Hume, $O f$ the rise and progress of the arts and sciences, Of commerce, 1987, pp. 111-137, 253-267). Em poucas palavras, a segurança da propriedade proporcionada pelas leis e a estabilidade das instituições políticas, no juízo de Hume, forneceriam os fundamentos indispensáveis ao progresso da civilização: "Mas as manufaturas, o conhecimento e o humanismo não são vantajosos apenas na vida privada. Eles difundem a sua influência benéfica sobre o público, e fazem o governo grande e próspero como faz os indivíduos afortunados e felizes" (Hume, Of refinement in arts, 1987, p. 272, destaque no original).

\footnotetext{
${ }^{3}$ Todas as traduções no presente artigo foram realizadas pelo autor.

4 “A interpretação whig confere mérito ou atribui importância àqueles episódios no passado vistos ou interpretados como contribuintes para algum aspecto do presente que certo historiador considera significativo ou desejável” (Hexter, 1978, p. 9). À época de Hume, essa visão propugnava que a história da Inglaterra consistira numa luta permanente pela liberdade e em favor do estabelecimento de uma monarquia constitucional. Em sua autobiografia, My own life (1776), ele qualificou "ridícula" a ideia de considerar a constituição inglesa antes dos Stuarts um plano regular de liberdade (Hume, 2004, p. 378).
} 
Processo similar ao descrito estaria em curso na Inglaterra ao tempo de Hume, segundo ele, devido ao progresso da instrução e da liberdade. O poder real não mais se apoiava na opinião dos súditos, preservando agora as suas prerrogativas por intermédio da permuta de cargos com os Comuns, cujo poder era assim retribuído na forma de favores do rei. Evitavam-se, dessa maneira, as facções, a desordem e a tirania resultantes da tentativa de se sobrepor a ambição irrefreada de uma parte ao conjunto da sociedade. O governo misto da Inglaterra no século XVIII, ao promover a paz interna e a ordem, eliminara o rancor religioso, estimulara o comércio, as manufaturas, a agricultura, as ciências e as artes, configurando, por tudo isso, um arranjo sábio e feliz. "Raras nações podem se orgulhar de tal período glorioso. Nem existe outro exemplo em toda a história da humanidade no qual tantos milhões de pessoas tenham se mantido unidas, por tanto tempo, de maneira tão livre" (Hume, Of the protestant succession, 1987, p. 508; consulte-se também Of the independency of parliament e Whether the British government inclines more to absolute monarchy, or to a republic).

Quando então se decide a escrever a história da Inglaterra, pareceu natural a Hume iniciar o relato com a ascensão de James I, pois este, no seu cálculo, seria o momento em que começara a se definir a estrutura política que julgava tão venturosa para a nação inglesa. Hume, de acordo com a sua orientação filosófica, sempre se manifestou contrário a rebeliões, conflitos e sectarismos por implicarem rompimento dos costumes e da ordem vigente 5 . Mesmo considerando legítimo o direito do povo de resistência à opressão, esse recurso, observa o escocês, deveria ser utilizado unicamente em casos extremos, quando a ruína da sociedade avultasse no horizonte. Doutra forma, as revoltas induziriam a autoridade a recorrer à tirania e ao uso da violência (Hume, Of passive obedience, 1987, pp. 488-492). Antes de iniciar a redação de History, Hume escreveu ao amigo Adam Smith explicando ser esta a razão de sua escolha do ponto no tempo em que iniciaria o trabalho:

Foi sob o reinado de James que a Câmara dos Comuns pela primeira vez passou a se erguer e então a disputa entre privilégio e prerrogativa começou. O governo, não mais oprimido pela enorme autoridade da Coroa, mostrou a sua inclinação; e as facções que se formaram na ocasião, tendo influência nos assuntos presentes, constituem a parte mais curiosa, interessante e instrutiva de nossa história. (Hume, 24 de setembro de 1752, in Greig, 2001, p. 168)

Vejamos então como Hume viria a analisar o reinado de James I em sua obra histórica maior, notadamente no tocante ao que denominou a luta pela liberdade e que, no século XVII, teria o orçamento real como ponto de convergência da contenda entre as facções opostas no cenário político da Inglaterra.

\footnotetext{
5 “O costume é aquele princípio, por meio do qual essa correspondência [entre a mente e a natureza] se efetivou, tão necessário à subsistência de nossa espécie e à regulação de nossa conduta em todas as circunstâncias e ocorrências da vida humana" (Hume, 1963, p. 55).
} 


\section{O COMEÇO DA DISCÓRDIA: O PARLAMENTO E JAMES I}

James I é descrito por Hume como um rei que herdara o trono de Elizabeth I (1558-1603) em uma transição pacífica, com o país estável e próspero ${ }^{6}$. Embora no início ainda subsistisse algum respeito dos Comuns pela autoridade real, as disputas com James I tornar-se-iam progressivamente mais agudas, em especial no suprimento de fundos para o governo, sempre aprovados em montantes inferiores às necessidades da $\mathrm{Coroa}^{7}$. Manifestações contra as proclamações reais, editadas durante os períodos de abstinência parlamentar, se fizeram frequentes. Outros pontos de oposição dos Comuns ao soberano viriam a aflorar nas fortes críticas à aliança com a Espanha, na exigência de maior rigor contra os católicos, na reafirmação do poder parlamentar de derrubar e processar ministros, na insatisfação com os atos das cortes reais, em suma, em praticamente todas as instâncias, domésticas ou externas, de exercício das prerrogativas do rei. Comentando a atuação do terceiro parlamento de James I, no qual se elaborou extenso documento de recriminação ao governo monárquico, Hume assim se expressou:

Por esta iniciativa corajosa, sem precedentes por muitos anos na Inglaterra e raramente adotada em tempos de paz, os Comuns atacaram de uma só vez as máximas favoritas de governo do rei; as medidas prudentes e pacifistas, a leniência no tocante à religião romana e o apego à aliança com a Espanha, da qual ele esperava grandes vantagens. O que mais lhe desgostou, porém, foi a aparente invasão de suas prerrogativas, e a pretensão dos Comuns, sob o manto de aconselhamento, de dirigir a sua conduta em pontos previamente admitidos como de competência exclusiva de gestão e orientação por parte do soberano. (History V, 1778, p. 90, destaque no original)

\footnotetext{
${ }^{6} \mathrm{O}$ rei James nasceu em 19 de junho de 1566, no Castelo Edimburgo, filho da rainha Mary I e de Henry Stuart, Lord Darnley. Após o assassinato do marido, do qual foi acusada, Mary viu-se forçada a abdicar em 24 de julho de 1567. Cinco dias depois, James VI foi consagrado rei da Escócia, com apenas 13 meses. Mary fugiu para a Inglaterra em 1568, onde foi mantida em cativeiro por duas décadas, julgada por conspiração e executada em 1587. James VI assumiu de fato o trono da Escócia em 1578, desposando Anna da Dinamarca em 23 de dezembro de 1589. Após a morte da rainha Elizabeth I, a coroação de James I como rei da Inglaterra teve lugar no dia 25 de julho de 1603 . Ele veio a falecer em 27 de março de 1625. ( Cf. Stewart, 2003.)

${ }^{7}$ A disposição dos eleitos no novo reinado ficou clara após manifestação de James I afirmando ser a existência do parlamento devida à graça do rei. "O estado monárquico é supremo sobre a terra, pois os reis não são apenas representantes de Deus neste mundo, sentados num trono divino, mas até mesmo pelo próprio Deus são considerados Deuses” (James I, Speech before Parliament, 21 de março de 1609, in MacArthur, 1996, p. 44). Um comitê dos Comuns, em seguida, elaborou documento de protesto no qual enfatizou que os atributos políticos dos representantes constituíam o seu direito e herança legítima, da mesma forma que os seus bens e propriedades (Hexter, 1978). Esta postura do rei foi causa adicional de suas dificuldades recorrentes com o parlamento: "James estava consciente de suas diversas virtudes e se considerava um monarca competente, mas estava menos ciente do fato de que a sua crença ardorosa no direito divino da monarquia e a sua autoconfiança fizeram-no ser impaciente, arrogante, pomposo e, às vezes, pontifical” (Mondi, 2007, p. 161).
} 
Quadro 1: Parlamentos de James I

\begin{tabular}{|c|c|c|c|}
\hline Ordem & Reunião & Dissolução & Sessões \\
\hline $1^{\circ}$ & 19 de março de 1604 & 9 de fevereiro de 1611 & 5 \\
\hline $2^{\circ}$ & 5 de abril de 1614 & 7 de junho de 1614 & 1 \\
\hline $3^{\circ}$ & 30 de janeiro de 1621 & 8 de fevereiro de 1622 & 1 \\
\hline $4^{\circ}$ & 12 de fevereiro de 1624 & 27 de março de 1625 & 1 \\
\hline
\end{tabular}

Fonte: www.historyofparliamentonline.org.

No trecho reproduzido, Hume admite, em primeiro lugar, que o parlamento nem sempre manifestara postura autônoma em favor das liberdades do povo, como alegavam certos intérpretes whigs da história política inglesa ${ }^{8}$. Além disso, sustenta ele terem sido os Comuns os primeiros a adotar uma estratégia agressiva, investindo frontalmente contra os atos da monarquia. James I, segundo Hume, possuía tendências autocráticas, especialmente em suas convicções sobre a origem divina do poder real, mas isso não fizera com que ele agisse diferentemente de seus predecessores, os quais lhe serviam de inspiração. Por esse motivo, o problema capital para James I não consistia em sua suposta tentativa de impor aos súditos um governo despótico. Antes, a dificuldade emanava de sua inaptidão em compreender que o ambiente político em que se movia não comportava mais atitudes próprias de uma época extinta, requerendo novas formas de interação com os parlamentares e que escapavam à sagacidade real:

$\mathrm{Na}$ Inglaterra, aquele poder quase ilimitado que havia sido exercido por aproximadamente um século, especialmente no último reinado, ele [James I] creditava somente ao berço real e ao título, não à prudência ou ao espírito dos monarcas, nem tampouco à conjuntura dos tempos. [...] Pois a arte de gerenciar os parlamentos, por meio do interesse próprio ou por conspiração, até então inútil ou de escassa utilidade, ainda não se tornara parte da política inglesa. (History V, 1778, pp. 19, 34; veja-se igualmente, pp. 126-128, 138)

A incapacidade do rei em controlar as novas forças políticas do país, se nascia de sua convicção na onipotência do poder real, apoiava-se igualmente na visão então prevalecente de que o parlamento consistia unicamente numa peça subsidiá-

\footnotetext{
${ }^{8}$ Um influente autor whig, o Visconde de Bolingbroke, em A dissertation upon parties (1733), contestara os defensores do poder real e afirmara o caráter universal da constituição britânica: "Estou seguro que eles devem estar mais do que cegos, se algum deles ainda existe, que não admita atualmente, e sob o arranjo presente, que nossa constituição é estritamente uma barganha, um contrato condicional entre o príncipe e o povo, como sempre foi, e ainda o é, entre o conjunto da nação e os seus representantes" (Bolingbroke, Carta XIII, 1754, pp. 200-201, itálicos nossos).
} 
ria ao exercício da monarquia, à mercê da vontade do soberano e da qual pouco haveria de se esperar em condições usuais. Ou seja, a instituição tinha o poder de elaborar leis, mas não de criá-las efetivamente sem a sanção do rei. E, o mais importante para Hume, historicamente o parlamento sempre se mostrara subordinado ao poder real, notadamente durante o período anterior dos Tudors na Inglaterra. Ou, como explicou ele as ações do rei Charles I que, a exemplo do pai, sempre se mostrou reticente em convocar eleições:

A história da Inglaterra jamais, até então, oferecera exemplos de algum grande movimento ou revolução originários da Câmara Baixa. E como a sua posição hierárquica, tanto da instituição quando de seus integrantes, era de segunda ordem, nada além da experiência fatal poderia engajar os príncipes a prestar o respeito devido àquela formidável assembleia. (History V, 1778, p. 170)

A Inglaterra de James I, conforme Hume, testemunharia o surgimento de duas visões distintas a respeito do arranjo constitucional prevalecente, as quais se encontravam ligadas a princípios políticos que fundamentariam os verdadeiros partidos do país. Na percepção dos homens pertencentes ao court party, o soberano desfrutava de autoridade absoluta e inquestionável, como a própria constituição da Inglaterra afiançava. O parlamento era criado e dissolvido por vontade real. Somente o príncipe merecia respeito e consideração. Ninguém que o desafiasse poderia viver impune nas terras do reino. A participação ocasional em uma assembleia não significava autorização para se deixar de lado a reverência pelo poder real e tampouco o predicado de se examinar os problemas domésticos permitia aos eleitos para tal finalidade a invasão dos domínios exclusivos do governo (History V, 1778, pp. 93-94, 192-193, 354-356). As iniciativas de James I, por mais arrogantes que se afigurassem, apoiavam-se na longa tradição de governos despóticos na Inglaterra, comandados por personagens fortes como Henry VIII ou Elizabeth I, para quem as regalias de emitir proclamações, de ordenar encarceramento, de impor empréstimos forçados, de determinar o recrutamento compulsório, de fixar taxas alfandegárias ou de conceder monopólios eram consideradas inteiramente naturais e imunes à contestação:

Os reis da Inglaterra, contudo, tinham exercido constantemente tais poderes e se em alguma ocasião o príncipe se viu na contingência de se submeter às leis promulgadas contra os mesmos, ele, na prática, sempre elidiu tais obstáculos e retornou à administração arbitrária anterior. Durante quase trezentos anos antes da coroação de James, a autoridade real, nesse particular, jamais fora questionada. [...] Em consequência destas ideias exaltadas de autoridade real, a prerrogativa derivada do precedente, além dos artigos de jurisdição, era suposta por muitos possuir um fundo inesgotável de poderes latentes passíveis de serem exercidos em qualquer emergência. (History V, 1778, pp. 126, 127-128). 
Já os partidários da liberdade, constituintes do country party, entendiam que se a instituição parlamentar nascera por desígnio de reis ancestrais, os princípios regentes da natureza humana ensinavam que os governos deviam a sua existência ao consentimento voluntário do povo. Jamais na Inglaterra, argumentavam esses indivíduos, se presenciara uma monarquia estrita. A despeito dos tempos de domínio estrangeiro ou de usurpação do trono por tiranos, a população sempre aguardara a oportunidade de reafirmar a forma mista de governo e a prevalência da constituição. Se o rei possuía ascendência divina, tudo o que fosse necessário ao exercício de seu mandato, como o parlamento, revestia-se de idêntica autoridade. Caso alguma instituição política tivesse que prevalecer, deveria ser a assembleia nacional, bastião da luta contra o poder despótico e em prol das liberdades sagradas dos súditos do reino (History V, 1778, pp. 94-95, 194-195, 352-354). De acordo com Hume, seria essa a visão do quadro político impregnada na mente dos parlamentares da Câmara Baixa da Inglaterra do século XVII:

Os líderes, homens de gênio independente e visão larga, passaram a regular a sua opinião mais pelas consequências futuras do que viam do que pelo precedente passado firmado antes deles; e se preocupavam menos em preservar a antiga constituição do que em estabelecer uma nova, mais livre e melhor. (History V, 1778, p. 42; veja-se, ainda, pp. 22, 39-42)

Em tais condições, estavam lançadas as sementes da discórdia entre o poder real e os representantes populares no século dezessete, cujo ponto nevrálgico, na avaliação de Hume, radicava-se no orçamento real: "O soberano já perdera aqueles fundos independentes por meio dos quais ele poderia subsistir sem o abastecimento regular de recursos pelo parlamento; e ele ainda não adquirira os meios de influenciar aquelas assembleias", explica Hume, ao que complementa: "O efeito desta situação, iniciada com a ascensão da casa Stuart, rapidamente alcançou grandes proporções e mais ou menos se propagou por todos os reinos desta infeliz família" (History V, 1778, p. 138).

Posteriormente, no quarto volume de History, Hume viria a assinalar que as dificuldades de James I no campo fiscal não poderiam ser atribuídas exclusivamente ao monarca escocês. Ele e seus sucessores, em verdade, teriam sido vitimados também pelo longo reinado de Elizabeth I. Para manter a dignidade e a independência em relação ao Parlamento, a rainha teria apelado de forma desmesurada à venda de concessões de monopólios e à alienação de terras da Coroa, prejudicando a economia nacional e comprometendo as receitas fundiárias dos mandatários subsequentes. Esse processo de dilapidação do patrimônio real tornara-se mais atrativo a Elizabeth I em vista de sua incapacidade de gerar prole, fato que lhe permitiu concentrar-se unicamente no exercício de seu reinado, sem preocupação quanto aos futuros soberanos (History IV, 1987, p. 371). 


\section{HUME E AS FINANÇAS DE JAMES I}

Antes de se passar à análise de Hume sobre as finanças de James I, é oportuno breve sumário da evolução das contas reais no período. O novo soberano herda de Elizabeth I uma dívida estimada em $£ 422$ mil devido às campanhas na Irlanda e à guerra com a Espanha. No primeiro parlamento do rei, na esteira do Gunpowder Plot (complô de católicos para explodir o parlamento quando da presença do rei, descoberto em 1605), o governo obtém em 1606 o voto de dois subsídios e quatro quintos, fundos que, somados à venda de terras pela Coroa, permitem importante abatimento da dívida pública, reduzida de $£ 735$ mil para $£ 280$ mil nos três anos seguintes ${ }^{9}$. Não obstante, as contas reais permanecem deficitárias. O tesoureiro Thomas Sackville determina a majoração unilateral das taxas sobre as mercadorias e a criação de tarifas alfandegárias adicionais (impositions). Em 1610, o novo tesoureiro Robert Cecil negocia um acordo (Great Contract) com o parlamento, envolvendo o recebimento de um valor fixo pelo rei em troca da extinção de certos direitos feudais da Coroa. Os Comuns, todavia, recusam a proposta, insistindo na revogação dos impostos criados à sua revelia. Após a morte de Cecil, em 1612, James I constitui a primeira Comissão do Tesouro, composta por seis membros e liderada por Henry Howard. As dificuldades financeiras da Coroa, porém, subsistem e novo parlamento é convocado em $1614 .{ }^{10} \mathrm{O}$ impasse rapidamente se estabelece no tocante à prerrogativa real de impor tributos, firmemente contestada pelos membros da Câmara Baixa. Em 1614, o tesouro é assumido por Thomas Howard, mantido no posto até 1618 . No período, a situação das contas reais continua instável, ensejando nova revisão das taxas incidentes sobre as mercadorias, assim como a

\footnotetext{
${ }^{9}$ O governo monárquico inglês no início do século XVII detinha recursos ordinários, como o aluguel das terras da Coroa, além de tributos feudais compreendendo a custódia do patrimônio de herdeiros menores (wardship), as taxas de herança de terras (relief) e os pagamentos em dinheiro para o resgate do rei ou cerimônias da realeza (aids), entre outros ingressos de menor expressão. As receitas alfandegárias compreendiam aquelas obtidas de tarifas tradicionais, bem como as concedidas por tempo determinado pelo parlamento, embora geralmente renovadas, como os direitos de tonnage e poundage incidentes sobre comércio exterior de lãs, peles, vinhos e tecidos. As receitas extraordinárias, que necessitavam de autorização parlamentar, compreendiam os impostos diretos como o décimo quinto (fifteenth) e o décimo (tenth), cujo valor total era fixo e repartido entre os condados, sendo coletados pelos próprios residentes. Os subsídios necessitavam de autorização do parlamento, resultando, contudo, de avaliação da riqueza dos contribuintes por parte de comissários. O governo possuía ainda as prerrogativas de adquirir suprimentos a preços constantes (purveyance) e de recrutar navios mercantes para a defesa da nação (ship money), as quais, com o tempo, se converteram em pagamentos pecuniários à Coroa (Braddick, 1996, pp. 49-55, 68-89, 91-95; sobre o sistema fiscal da Inglaterra após a Revolução Gloriosa, consulte-se Brewer, 1989, cap. 4).

${ }^{10} \mathrm{O}$ conjunto de conselheiros reais encontrava-se dividido em dois grupos. O primeiro, liderado por Henry Howard, Conde de Northampton, era antiparlamentar, pró-católico e favorável ao acordo nupcial de Charles com a infanta da Espanha Ana Maria (Spanish Match). Já o grupo majoritário de conselheiros mostrava-se inclinado à negociação com o parlamento como forma de preservar a boa relação do rei com seus súditos, estando composto, entre outros, o Arcebispo George Abott e Francis Bacon. Essa divisão perdurou durante todo o reinado de James I (Willson, 1940; Russell, 1976).
} 
tomada de empréstimos junto aos concessionários do governo e a cidade de Londres, garantidos pelas receitas de projetos ligados à alienação das florestas e ao cultivo das terras reais, mas que não chegariam a se materializar (Dietz, 1932, pp. 100-181; Ashton, 1957; Lindquist, 1984; Hoyle, 1994; Cramsie, 2002, pp. 67-150).

Em 1618, nova Comissão do Tesouro é formada sob a liderança de George Abbot, Arcebispo de Canterbury. A estratégia financeira do período privilegiava a venda de títulos de nobreza, assim como a concessão de monopólios e patentes, emitidos em volume inédito até então. Em 1621, a invasão do Palatinado por forças austríacas, governado por Frederick V, marido da filha de James I, Elizabeth Stuart, coage o rei a convocar novo parlamento visando à arrecadação de fundos para a restauração de seu genro, quando obtém apenas dois subsídios (cerca de $£ 70$ mil), valor insuficiente para uma campanha militar. O último tesoureiro de James I, Lionel Cranfield, designado ao cargo em 1621, procurou implantar severo controle das contas, mas assistiu seus esforços serem sobrepujados pela expansão desordenada dos gastos do governo. Em 1623, George Villiers, Duque de Buckinham, e o príncipe Charles empreendem onerosa viagem secreta ao continente para consumar o casamento do herdeiro com a infanta Ana Maria, buscando assim reverter a ocupação espanhola do Palatinado, então sob domínio de Philip IV, da Casa dos Habsburgos. A iniciativa fracassa e os dois aventureiros retornam determinados a declarar guerra à Espanha, persuadindo James I a convocar novo parlamento em 1624. Cranfield redige memorando contrário à guerra devido à frágil situação das finanças reais, enquanto o monarca, relutante, solicita aos Comuns seis subsídios e doze quintos ( $£ 500$ mil) para o esforço bélico. São autorizados, no entanto, apenas três subsídios e três quintos. Antes do final da sessão, Cranfield é derrubado por pretensa corrupção, sendo aprovado ainda o fim das concessões de monopólios (Dietz, 1932, pp. 182-223; Ashton, 1957; Mayes, 1957; Cramsie, 2002, pp. 151-204).

Retornando então a Hume, inicia ele a análise das finanças de James I por meio de uma estimativa dos ingressos e desembolsos do governo no ano de 1617, reproduzida na Tabela 1. A fonte das informações não é especificada claramente, sendo mencionado apenas terem sido colhidas de uma declaração resumida das receitas de Sua Majestade. De qualquer modo, destaca-se, no campo das finanças ordinárias, um déficit corrente de $£ 36$ mil, enquanto, no tocante às contas ditas extraordinárias acumuladas entre 1603 e 1617, estão relacionados recursos oriundos de alienação de terras da Coroa, perfazendo $£ 775$ mil, além de ingressos como subsídios parlamentares, doações do rei da França, vendas de títulos e outros valores, somando $£ 1.425$ milhão. No campo dos desembolsos extraordinários, o valor apresentado por Hume alcança $£ 2$ milhões, ao que se adicionam ainda despesas em torno de $£ 400$ mil na forma de presentes. Os números não são detalhados, mas a conclusão de Hume mostra-se importante para o que segue: "No todo, uma razão suficiente fica clara, em parte por influência das despesas necessárias, em parte por ausência de rígida economia, pela qual o rei, desde cedo em seu reinado, viu-se 
profundamente em dívida e enfrentou grande dificuldade para viabilizar o seu governo" (History V, 1778, p. 135) $)^{11}$.

Do ponto de vista das despesas, Hume esclarece que o público e a Coroa estiveram livres da obrigação de sustentar um exército permanente, uma vez que o rei não possuía sequer um único regimento para emprestar força a seus atos e proclamações. As esparsas milícias da Inglaterra, à época, somavam 160 mil homens, sendo difícil até mesmo constituir um regimento montado com 2 mil cavaleiros por absoluta falta de animais. Esta situação peculiar da monarquia inglesa, de acordo com Hume, fez os reis da linhagem Stuart particularmente sensíveis às investidas do parlamento. Isso porque a autoridade da Coroa restava apoiada unicamente na opinião dos súditos, formada pela tradição e pelos exemplos passados. O rei, portanto, não dispunha de recursos monetários ou mesmo de um exército para sustentar as suas prerrogativas que, uma vez suprimidas, deixá-lo-iam sem meios efetivos de salvaguardar a sua dignidade e assegurar a aplicação das leis. Se as liberdades individuais haviam se tornado mais claras e seguras pela ação resoluta do parlamento contra James I, as liberdades públicas resultaram fragilizadas por tal situação em virtude da debilidade do respeito ao poder real. Ou, como anotou Hume: "Parece uma verdade necessária, embora melancólica, que em todo o governo o magistrado deve possuir ou um ingresso substancial ou uma força militar a fim de executar as leis e garantir a própria autoridade" (History V, 1778, p. 129).

Tabela 1: Finanças da Coroa 1617

\begin{tabular}{|c|c|c|c|}
\hline Receitas ordinárias & Valor & Despesas ordinárias & Valor \\
\hline Rendas de terras da Coroa & 80.000 & Gastos regulares & 486.000 \\
\hline Alfândega & 190.000 & & \\
\hline Custódia e outros & 180.000 & & \\
\hline Total & 450.000 & Total & 486.000 \\
\hline $\begin{array}{l}\text { Receitas extraordinárias } \\
1603-1617\end{array}$ & & $\begin{array}{l}\text { Despesas extraordinárias } \\
1603-1617\end{array}$ & \\
\hline Vendas de terras & 775.000 & Despesas extraordinárias & 2.000 .000 \\
\hline \multirow{2}{*}{$\begin{array}{l}\text { Diversos } \\
\text { (subsídios, doações, } \\
\text { concessão de títulos) }\end{array}$} & 1.425 .000 & Presentes & 400.000 \\
\hline & & Déficit & -200.000 \\
\hline Total & 2.200 .000 & Total & 2.200 .000 \\
\hline
\end{tabular}

Notas: Valores em libras esterlinas.

Fonte: History of England V, 1778, p. 135.

\footnotetext{
${ }^{11}$ Braddick (1996, p. 26) estimou as despesas médias anuais com a casa real entre $£ 112$ mil e $£ 125$ mil para o período da rainha Elizabeth I e em $£ 199$ mil para o reinado de James I. Um contemporâneo assim descreveu as festas celebradas na Corte inglesa à época do rei escocês: "Nunca vi tamanha falta de ordem, de discrição e de sobriedade como agora [...] nos encontramos, por aqui, como se o demônio tivesse incitado todos os indivíduos a se esvair em devassidão selvagem, em excessos, e na dissipação do tempo e da moderação" (citado em Stewart, 2003, p. 236).
} 
No que se refere aos gastos com a marinha, a frota total ao fim do reinado de Elizabeth I contemplaria 33 navios, além das embarcações menores (pinaças). James I, contudo, reconhece Hume, teria se empenhado no reforço da esquadra. Entre 1619 e 1623 ele construiu 10 novos navios de grande porte, um dos quais com 64 canhões, tendo investido no setor valores da ordem de $£ 50$ mil ao ano, além de $£ 36$ mil anuais na forma de madeira das florestas reais. As naus da marinha mercante, por sua vez, poderiam ser mobilizadas para eventual esforço de guerra, caso necessário, enquanto os marujos ocupados na atividade estariam ao redor de 10 mil, número considerável, mas aquém de outras nações continentais, posto que a frota inglesa envolvida nos negócios com Holanda contava com 60 embarcações, quando as naus holandesas atracando em portos ingleses à época somavam dez vezes mais. Esta situação, pondera o escocês, refletia ainda o estado incipiente das manufaturas inglesas, já que à época o país se destacava apenas na construção naval e na fundição de canhões, permanecendo atrasado em relação às artes mais elaboradas praticadas na Itália, na Holanda e na França. A quase totalidade do mercado doméstico inglês compreendia os tecidos de lã, em parte exportados para processamento na Holanda (History V, 1778, pp. 141-143).

James I, tampouco, aplicara os seus recursos no desenvolvimento das artes e das ciências, tendo ele unicamente, devido às suas preocupações religiosas, construído uma faculdade em Chelsea para o ensino de vinte estudantes encarregados de refutar os dogmas papistas e puritanos. Nada tampouco, até os dias de Hume, registra o filósofo com pesar, fora instituído por qualquer monarca para a consolidação e o aperfeiçoamento da língua inglesa. $O$ quadro se apresentava ainda mais sombrio em vista dos esforços de Francis Bacon em favor de uma filosofia natural, mas que não frutificaram no tempo de James I. "O único encorajamento que o soberano da Inglaterra jamais concedeu a qualquer coisa parecida com a ciência foi este efêmero estabelecimento de James, instituição verdadeiramente inútil" (History V, 1778, p. 132).

Ainda, do ponto de vista das despesas de James I, embora Hume indique que os gastos com o Palatinado teriam, com efeito, representado sensível fardo para o governo $^{12}$, a razão última das dificuldades financeiras do soberano residiria em sua incorrigível prodigalidade. O rei, a rigor, admite Hume, não teria se envolvido em dispêndios luxuosos com indumentária, castelos ou amantes, mas demonstrara grande frivolidade no manejo dos recursos à sua disposição ${ }^{13}$. Esse comportamen-

\footnotetext{
${ }^{12}$ Em 1624, Cranfield relatou aos parlamentares que as despesas com o Palatinado haviam alcançado $£ 1.158$ milhão, englobando a viagem de Charles a Espanha, a diplomacia, a defesa do território, entre outros gastos relacionados, para receitas extraordinárias concomitantes de apenas $£ 371$ mil (Cramsie, 2002, p. 198).

${ }^{13}$ Alguns dos gastos extraordinários da Corte são discriminados por Cramsie (2002, pp. 194-195; veja-se, igualmente, Dietz, 1932, pp. 103-108): "Em 1622, o consumo de vinhos e frutas havia alcançado proporções glutônicas quando comparado ao padrão de 1619 ( $£ 8.989$ contra $£ 4.304$ ). Joias e presentes extravasaram a dotação de $£ 5.000$ para mais de $£ 24.000$ [...] Finalmente, pensões, gratificações, anuidades e prêmios ampliaram-se a níveis preocupantes, saindo de $£ 62.895$ (1619) para $£ 73.839$ (1622),
} 
to resultara de seu caráter humanista, mas marcado por personalidade fraca, estando ele mais afeito a formular princípios gerais do que a conduzir de forma apropriada qualquer assunto complexo (History V, 1778, pp. 121-122). Hume assim descreve um episódio típico da natureza volúvel de James I:

Certo dia, diz-se, enquanto ele estava entre alguns de seus cortesãos, um carregador passou com um lote de dinheiro que levava ao Tesouro. $\mathrm{O}$ rei observou que Rich, mais tarde Conde de Holland, um de seus belos e agradáveis favoritos, sussurrou alguma coisa a alguém próximo. Após indagar sobre o fato, o rei constatou que Rich dissera: quão feliz aquele dinheiro me faria! Sem hesitar, James deu-lhe toda a quantia, avaliada em $£ 3$ mil. E aduziu: você se acha muito feliz por obter tamanha soma em dinheiro; mas eu sou mais feliz por ter a oportunidade de agraciar um homem valoroso a quem aprecio. (History V, 1778, pp. 136-137, itálicos no original)

Tais atitudes abusivas, na ótica do autor escocês, decorreriam da concepção equivocada de James I a respeito do poder real, e que o induzia a se equiparar aos poderosos monarcas hereditários europeus, imaginando que por se encontrar na mesma condição de seus congêneres, desfrutava idênticas prerrogativas. Por conta dessa visão de um poder majestático e sem limites, reforçada pela tradição autoritária dos soberanos ingleses dos séculos precedentes, o irrevogável poder real de contornar as leis e as restrições habituais do cargo em situação de necessidade terminou sendo estendido a quase todos os casos de mera conveniência pessoal. Consequentemente, se a provisão de fundos à Coroa por parte do parlamento destinava-se a suprir apenas as demandas extraordinárias e imperativas do governo, não haveria razão aparente, aos olhos do rei, para que procedimento similar deixasse de ser adotado nas demais circunstâncias, pois ao soberano todos os gastos associados ao exercício da realeza pareciam-lhe igualmente inevitáveis. E essa tendência teria se agravado ainda mais devido ao aumento nos preços provocado pela expansão na oferta europeia dos metais preciosos após a descoberta das Índias Ocidentais, sem que as receitas do governo mantivessem o passo com a inflação. O efeito destes dois fatores seria desastroso para James I, como ressalta Hume ao descrever de maneira engenhosa o poderoso efeito da disjuntiva entre a conduta real e os costumes em transformação:

Mas enquanto o dinheiro assim afluía à Inglaterra, devemos observar que, ao mesmo tempo, e provavelmente por conta desta mesma causa, as artes e a indústria de todos os tipos receberam poderoso estímulo; e a elegância em cada entretenimento da vida se tornou mais bem conhecida e mais cultivada em todos os estratos da população. Os servos do rei,

de forma alarmante num tempo em que Cranfield tinha projetado reduzir tais rubricas a $£ 22$ mil. Tratava-se da história familiar de financiar no curto prazo despesas em contínua expansão". 
civis e militares, assim como os cortesãos e os ministros, requisitavam provisões mais amplas de seu empobrecido príncipe, e não se contentavam com a mesma simplicidade de vida que satisfizera os seus ancestrais. O próprio príncipe começou a considerar uma expansão na pompa e no esplendor como requisito para amparar a dignidade de seu caráter e preservar a mesma superioridade sobre os súditos que os seus predecessores haviam usufruído. Alguma igualdade também, e proporção em relação aos demais soberanos da Europa, era natural que ele o desejasse; e como eles tinham ampliado as suas receitas e multiplicado as suas taxas, o rei da Inglaterra julgou razoável que os seus súditos, em geral tão ricos quanto os dos outros reinos, deveriam suportar com igual paciência alguns encargos e impostos adicionais (History V, 1778, p. 39; consulte-se também pp. 126-128)

Passando ao campo das receitas, Hume explica que quando o parlamento concedeu originalmente o direito de poundage ao soberano, não tinha em mira qualquer taxa em particular, sendo cobrado um xelim por pence, ou $5 \%$ sobre todas as mercadorias. Coubera ao privy council, à época, fixar os preços dos produtos e as taxas correspondentes, providência adotada, contudo, antes do influxo de ouro das Índias Ocidentais, que elevara posteriormente os preços e, portanto, reduzira a carga efetiva dos valores tributados até então. James I, a exemplo das rainhas Mary I (1553-1558) e Elizabeth I, julgou apropriado revisar os preços das mercadorias sobre os quais incidiriam os novos encargos uma vez que a avaliação original fora produzida pelo mesmo privy council ao qual ele determinara proceder à atualização dos valores. As novas estimativas, na avaliação de Hume, teriam sido moderadas, uma vez que essa fonte de arrecadação crescera apenas de $£ 127$ mil para $£ 190$ mil durante todo o reinado. Além disso, as mercadorias que compunham o consumo de subsistência, assim como as matérias-primas das manufaturas, ficaram isentas das novas taxas de James I. O rei, todavia, não antecipara a oposição sistemática do parlamento, que chegou a abolir essas imposições reais, iniciativa derrubada adiante pelos Lordes. De qualquer sorte, o episódio sinalizou o advento de uma nova era nas relações entre a Coroa e o parlamento, pois os integrantes da Câmara Baixa deram mostra efetiva de não aceitarem mais o argumento do direito real à tributação fundado no precedente (History V, 1778, pp. 41-42).

Quanto aos subsídios e aos décimos quintos, este segundo tipo de fundos autorizado pelo parlamento correspondia à proporção taxada dos bens móveis dos indivíduos, conforme avaliação realizada ao tempo de Edward III (1312-1377), de modo que cada condado pagava determinada soma recolhida pelos próprios residentes. Nas cidades, esta mesma taxa era denominada décimo, e ambas as formas de arrecadação inteiravam a quantia fixa de $£ 29$ mil para todo o país. Já o valor dos subsídios não era constante. No oitavo ano de Elizabeth I (1761), ele atingia $£$ 120 mil, tendo declinado para $£ 78$ mil no décimo quarto ano (1767), continuando em queda daí em diante. Os subsídios, na forma prevista nos estatutos, compreendiam quatro xelins por libra na avaliação das terras, e dois xelins e oito pence por 
libra nos bens móveis em todos os condados. Os coletores elaboravam uma estimativa do que cada indivíduo deveria pagar conforme a riqueza por ele possuída em um único condado, deixando de fora eventual patrimônio em outras localidades. Como essas avaliações baseavam-se naquelas realizadas no passado junto aos ancestrais, ou eram calculadas por comparação com indivíduos de riqueza equivalente, tal procedimento, por si só, impedia os subsídios de aumentarem com o tempo, de acordo com a inflação dos preços e das rendas. Quando a concessão dos mesmos se tornou mais frequente no final do reinado de Elizabeth I, explica o escocês, sempre que as rendas diminuíam ou as terras eram vendidas, os proprietários davam notícia aos coletores sobre a redução de seus rendimentos e do patrimônio. $\mathrm{O}$ mesmo, contudo, não sucedia nas localidades ou situações em que se presenciava o caso inverso, pois todos procuravam ocultar das autoridades os ganhos em terras ou nas rendas auferidas, processo que trabalhava em franco prejuízo do Tesouro ${ }^{14}$. "E para tornar as coisas piores", conclui então Hume, "as alterações ocorridas nas propriedades neste período foram, em geral, desfavoráveis à Coroa. Os pequenos proprietários, ou os homens de vinte libras, continuaram a declinar. Mas quando os seus lotes foram abocanhados por um proprietário maior, o novo comprador não aumentava o seu subsídio" (History V, 1778, p. 138).

Numa perspectiva de longo prazo, Hume indicou três razões fundamentais para o levante parlamentar do século XVII contra James I. A primeira envolvia o renascimento das letras e do conhecimento no continente europeu por obra dos aperfeiçoamentos nas artes da produção mecânica, das melhorias na navegação, das viagens pelo mundo e do culto aos clássicos da Antiguidade. Tudo isso permitira a fermentação de novas ideias direcionadas à limitação dos poderes dos governos monárquicos. De outra parte, a descoberta de ouro e prata nas Índias Ocidentais fizera por elevar os preços das provisões na Europa sem que os rendimentos da Coroa acompanhassem a inflação correspondente, reduzindo os príncipes à penúria em meio à prosperidade dos súditos, que assim puderam progredir sem serem onerados por exações abusivas para o financiamento de custosas expedições militares. Com a expansão das artes em geral, os servidores da Coroa e os cortesãos requisitavam maiores despesas, situação agravada pelo desleixo financeiro de James I em sua pretensão de emular o fausto das cortes europeias. Por fim, as transformações econômicas da Inglaterra, particularmente o avanço do comércio, a demanda por bens de luxo por parte da aristocracia fundiária e a livre negociação das terras, haviam concentrado riqueza e propriedade nas mãos dos Comuns que, com base nesta nova condição econômica, se motivaram a buscar garantias mais sólidas para a liberdade, posicionando-os na vanguarda da ação política no período (History V, 1778, pp. 18-20, 39-40, 137-138).

\footnotetext{
${ }^{14}$ Russell (1976) indica a queda histórica no valor dos subsídios como uma das razões da dificuldade dos parlamentos em extrair concessões dos reis no século XVII, fato que aguçou o conflito entre as partes, uma vez que os montantes a serem concedidos sempre se mantinham aquém das demandas crescentes do governo.
} 


\section{CONSIDERAÇÕES FINAIS}

Nos parágrafos precedentes, evidenciou-se que Hume elaborou análise coerente a respeito das finanças do rei James I, tanto nos seus aspectos políticos quanto econômicos. Em que pese a sua tese sobre o peso da longa tradição na sustentação dos governos, Hume, de fato, elaborou uma narrativa do largo processo de transformação política da Inglaterra no século XVII. Poder-se-iam apontar certas limitações de seu texto em vista da literatura moderna sobre o assunto, mas isso corresponderia a uma iniciativa por demais apartada do objetivo do presente $\operatorname{artigo~}^{15}$. De qualquer modo, Hume apontou com clareza que os conflitos financeiros do período entre parlamento e o soberano nasciam, a rigor, de modificações de longo alcance engendradas tanto na consciência política da sociedade quanto na condição econômica superior dos novos detentores da riqueza da nação. Com isso, surgiram divisões políticas apoiadas em princípios gerais de atribuição do poder que definiram os campos em confronto na Inglaterra do século XVII envolvendo, de um lado, os Comuns e, de outro, a monarquia, constituindo-se as receitas reais no principal território de disputa. Ao manterem os reis afastados de guerras continentais por quase dois séculos, os parlamentares viabilizaram o enriquecimento comercial dos súditos e, por consequência, de seus representantes, ao mesmo tempo em que a Coroa tornava-se cada vez mais dependente dos fundos autorizados com grande dificuldade pela Câmara Baixa. A contenda prolongar-se-ia até a queda de James II (1685-1688), durante a Revolução Gloriosa, quando se estabelecem finalmente as bases da nova etapa de liberdade do país, na qual se asseguram os direitos individuais e o equilíbrio de forças entre as instâncias do poder central.

\section{REFERÊNCIAS BIBLIOGRÁFICAS}

ASHTON, R. Deficit finance in the reign of James I. The Economic History Review, New Series, v. 10, n. 1, p. 15-29, 1957.

BRADDICK, M.J. The nerves of state. Taxation and the finance of the English state, 1558-1714. Manchester: Manchester University Press, 1996.

BREWER, John. The sinews of power. War, money and the English state, 1688-1783. London: Unwin Hyman, 1989.

BOLINGBROKE, H.S.J. A dissertation upon parties: In several letters to Caleb d'Anvers. London: R. Franklin, $8^{\text {th }}$ ed., 1754.

\footnotetext{
${ }^{15}$ Assim, por exemplo, embora reconheça os excessos de James I, Braddick (1996, pp. 21-34) entende que as despesas do rei mantiveram-se dentro do tolerável, porquanto o grande desafio das finanças públicas da Inglaterra nos séculos XVI e XVII residiu no imenso custo de manutenção dos aparatos militar e naval, os quais, após a Guerra Civil, tornaram-se permanentes, sobrecarregando excessivamente o orçamento real (veja-se, igualmente, Brewer, 1989, pp. 29-134). Já Russel (2011, pp. 154-176) ressalta que o valor fixo das remunerações dos oficiais da Coroa perante a inflação do século e meio precedente teria atuado como fator preponderante a pressionar James I na concessão de retribuições extraordinárias aos que lhe serviam. Tais considerações parecem, contudo, complementar a análise de Hume ao invés de contraditá-la.
} 
CRAMSIE, J. Kingship and crown finance under James IV and I, 1603-1625. Suffolk: St. Edmundsbury, Royal Historical Society, 2002.

DIETZ, F.C. English public finance 1558-1641. New York: The Century, 1932.

GRAHAM, R. The great infidel. A life of David Hume. Edinburgh: Birlinn, 2006.

GRAMPP, W.D. Economic liberalism. New York: Random House, 2 vls., 1965.

GREIG, J.Y.T. (ed.). The letters of David Hume. Oxford: Oxford University Press, v. I, 2011.

HOYLE, R.W. Crown, parliament and taxation in Sixteenth-century England. English Historical Review, p. 1174-1196, Nov 1994.

HEXTER, J.H. Power struggle, parliament, and liberty in early Stuart England. The Journal of Modern History, v. 50, n. 1, p. 1-50, 1978.

HUME, D. Essays. Moral, political and literary. Indianapolis: Liberty Fund, 1987. . Enquiries concerning the human understanding. Oxford: Glasgow, 1963.

. History of England. Volumes I-VI. Indianapolis: Liberty Classics, Reprodução da última edição revista por Hume, 1778.

My own life [1776]. In: R. GRAHAM. The great infidel. A life of David Hume. Edinburgh: Birlinn, 2006.

JAMES I. Speech Before Parliament, March 21, 1609. In B. MacArthur (ed.). The Penguin book of historic speeches. Penguin Books, London, 1996.

JOHNSON, E.A. Predecessors of Adam Smith. New York: Augustus M. Kelley, 1960.

LINDQUIST, P. The failure of the Great Contract. The Journal of Modern History, v. 57, n. 4, p. 617$651,1985$.

MAYES, C.R. The sale of peerages in early Stuart England. The Journal of Modern History, v. 29, n. 1, p. 21-37, 1957.

MONDI, M. The speeches and self-fashioning of King James VI and I to the English Parliament, 16041624. Constructing the Past, v. 8, n. 1, p. 139-182, 2007.

MOSSNER, E.C. The life of David Hume. Austin: University of Texas, 1954.

NORTON, D.F., POPKIN, R.H. David Hume: philosophical historian. Indianapolis: Bobs-Merril, 1965.

O'BRIEN, K. Narratives of Enlightenment. Cosmopolitan history from Voltaire to Gibbon. Cambridge: Cambridge University Press, 2005.

PHILliPSON, N. David Hume. The philosopher as historian. London: Penguin, 2011.

RUSSELL, C. Parliamentary history in perspective, 1604-29, History, n. lxi, p. 1-27, 1976.

. King James VI \& I and his English parliaments. Oxford: Oxford University Press, 2011.

SCHMIDT, C.M. David Hume: Reason in history. University Park: Pennsylvania State University, 2003. STEWART, A. The cradle king. A life of James VI and I. London: Chatto \& Windus, 2003.

TAYLOR, W.L. Francis Hutcheson and David Hume as predecessors of Adam Smith. Durham: Duke University Press, 1965.

THE HISTORY OF PARLIAMENT. British political, social and local history. Disponível em <http:// www.historyofparliamentonline.org/research/parliaments>. Acesso em 12 de novembro de 2012.

WEXLER, V.G. David Hume and the History of England. Philadelphia: The American Philosophical Society, 1979.

WENNERLIND, C., SCHABAS, M. (eds.) David Hume's political economy. London: Routledge, 2008.

WILLSON, D.H. Summoning and dissolving parliament, 1603-25. The American Historical Review, v. 45 , n. 2, p. 279-300, 1940. 